\title{
Formalin infiltration of ductus arteriosus in cyanotic congenital heart disease
}

\author{
JOHN E DEANFIELD, PHILIP G REES, CATHERINE M BULL, \\ MARC DE LEVAL, JARDA STARK, FERGUS J MACARTNEY, \\ JAMES F N TAYLOR
}

From the Thoracic Unit, The Hospital for Sick Children, Great Ormond Street, London

SUMMARY Formalin infiltration of the ductus arteriosus was performed in 13 neonates with pulmonary atresia (three with ventricular septal defect, two with tricuspid atresia, and eight with intact ventricular septum, one of whom had Ebstein's anomaly) in an attempt to maintain duct patency. Nine patients had an additional retrograde pulmonary valvotomy and one a Blalock-Taussig shunt. The mean preoperative systemic $\mathrm{Po}_{2}$ was $31 \mathrm{mmHg}$ and rose significantly to $46 \mathrm{mmHg}$ after operation. However, the $\mathrm{PO}_{2}$ rose in only two of four patients who had formalin infiltration alone. There were five early deaths and three had clinical evidence of duct closure. Four patients needed further surgery (systemicpulmonary artery shunt) within eight days. Seven of eight surviving patients were shown to have a closed duct at repeat cardiac catheterisation (two to 13 months after operation). The eighth died before restudy. There were four late deaths, one following late reoperation and the other three within five months of early reoperation.

These results suggest that formalin infiltration cannot ensure long-term duct patency. As short-term patency can be maintained more reliably by prostaglandin administration, we have abandoned the operation.

In some congenital cardiac conditions pulmonary blood flow is dependent, either largely or exclusively, on patency of the ductus arteriosus. When this structure constricts, in the neonatal period, progressive hypoxaemia and acidaemia result. The introduction of prostaglandin infusion to maintain patency of the ductus arteriosus in the short term has facilitated management, but palliative surgery is still required to establish adequate pulmonary blood flow on a more permanent basis. This may involve either a pulmonary valvotomy and/or a systemic to pulmonary shunt. Rudolph et al. ${ }^{1}$ described, in 1975, a technique of infiltrating the ductus arteriosus with formalin in an attempt to maintain its long-term patency. Four cases were described with good short-term results. Between 1977 and October 1979 formalin infiltration of the ductus arteriosus was performed in 13 neonates at The Hospital for Sick Children, Great Ormond Street. This communication reports our experience with the technique.

Received for publication 27 November 1980

\section{Subjects and methods}

Ductus infiltration was undertaken as part of the surgical management of 13 patients with ductdependent congenital heart disease. There were eight cases of pulmonary atresia with intact ventricular septum, one of whom had Ebstein's malformation of the tricuspid valve, three cases of pulmonary atresia with ventricular septal defect, and two cases of pulmonary atresia with tricuspid atresia.

The technique followed for formalin infiltration was as described by Rudolph et al. ${ }^{1}$ Ten per cent formaldehyde solution coloured with methylene blue was injected beneath the adventitia of the ductus arteriosus, an attempt being made to infiltrate the whole circumference. The spread of the blue dye was a good indicator of the extent of the infiltration.

The records of the 13 patients were reviewed retrospectively. Details of diagnosis and the surgical procedures associated with the duct infiltration were noted. Pre- and postoperative arterial $\mathrm{PO}_{2}$ were recorded and, if prostaglandin infusion was used perioperatively, its influence on 
the arterial $\mathrm{Po}_{2}$ noted. In order to assess the longterm patency of the ductus arteriosus, survival after duct infiltration, clinical evidence of duct patency, postoperative cardiac catheterisation data, the need for further surgery, and necropsy findings were reviewed.

A paired sample $t$ test was employed to test the significance of changes in arterial $\mathrm{Po}_{2}$ resulting from surgery and prostaglandin infusion.

\section{Results}

The diagnosis, age at initial surgery, and type of initial surgery of the 13 patients are shown in the Table.

rable Clinical data on 13 patients undergoing formalin infiltration of ductus arteriosus

\begin{tabular}{|c|c|c|c|}
\hline Case no. & Diagnosis & $\begin{array}{l}\text { Age at } \\
\text { operation } \\
\text { (d) }\end{array}$ & Operation \\
\hline 1 & Pulm atresia + VSD & 5 & Duct infiltration \\
\hline 2 & $\begin{array}{l}\text { Pulm atresia }+ \\
\text { tricuspid atresia }\end{array}$ & 3 & Duct infiltration \\
\hline 3 & $\begin{array}{l}\text { Pulm atresia }+ \\
\text { Ebstein's anomaly }\end{array}$ & 5 & Duct infiltration \\
\hline 4 & Pulm atresia & 5 & Duct infiltration \\
\hline 5 & Pulm atresia & 2 & $\begin{array}{l}\text { Duct infiltration }+ \\
\text { pulm valvotomy }\end{array}$ \\
\hline 6 & Pulm atresia & 1 & $\begin{array}{l}\text { Duct infiltration }+ \\
\text { pulm valvotomy }\end{array}$ \\
\hline 7 & Pulm atresia & 6 & $\begin{array}{l}\text { Duct infiltration }+ \\
\text { pulm valvotomy }\end{array}$ \\
\hline 8 & Pulm atresia & 1 & $\begin{array}{l}\text { Duct infiltration }+ \\
\text { pulm valvotomy }\end{array}$ \\
\hline 9 & Pulm atresia & 2 & $\begin{array}{l}\text { Duct infiltration }+ \\
\text { pulm valvotomy }\end{array}$ \\
\hline 10 & Pulm atresia + VSD & 4 & $\begin{array}{l}\text { Duct infiltration }+ \\
\text { pulm valvotomy }\end{array}$ \\
\hline 11 & Pulm atresia + VSD & 5 & $\begin{array}{l}\text { Duct infiltration }+ \\
\text { pulm valvotomy }\end{array}$ \\
\hline 12 & $\underset{\text { tricuspid atresia }}{\text { Pulm atresia }+}$ & 9 & $\begin{array}{l}\text { Duct infiltration }+ \\
\text { pulm valvotomy }\end{array}$ \\
\hline 13 & Pulm atresia & 1 & $\begin{array}{l}\text { Duct infiltration + } \\
\text { pulm valvotomy } \\
\text { + L Gortex }\end{array}$ \\
\hline
\end{tabular}

VSD, ventricular septal defect. $\quad L$, left

All patients presented with cyanosis and were transferred to the Thoracic Unit in the first week of life. All underwent cardiac catheterisation and angiocardiography on the day of admission. A prostaglandin $\mathrm{E}_{1}$ infusion (maximum dose $0 \cdot 1 \mu \mathrm{g} / \mathrm{kg}$ per min) was started before operation in 12 of the 13 patients and was discontinued in all cases in the immediate postoperative period. All the patients were less than 10 days old at the time of operation. Formalin infiltration of the ductus arteriosus was performed as an isolated procedure in four patients. An additional retrograde pulmon- ary valvotomy was carried out in nine patients and a left modified Blalock-Taussig shunt with a $4 \mathrm{~mm}$ Gortex conduit in one patient. ${ }^{2}$

Fig. 1 shows the systemic arterial $\mathrm{Po}_{2}$ levels at presentation, after prostaglandin treatment, and after operation (prostaglandin treatment having been withdrawn). The mean systemic arterial $\mathrm{Po}_{2}$ at presentation was $31 \mathrm{mmHg}$ (standard error of mean 2.6) and after surgery $46 \mathrm{mmHg}$ (SEM 3.4). The improvement in systemic arterial $\mathrm{Po}_{2}$ on prostaglandin treatment was significant $(p<0.001)$ and this improvement was maintained when prostaglandin was stopped after operation $(p<0.01)$. In the four patients who underwent duct infiltration as the sole procedure (cases 1, 2,3, and 4), however, the systemic arterial $\mathrm{PO}_{2}$ improved in two, remained unchanged in one, and fell in one case.

\section{SUBSEQUENT COURSE}

Early death

Five patients (cases 1, 2, 3,6, and 10) died in the

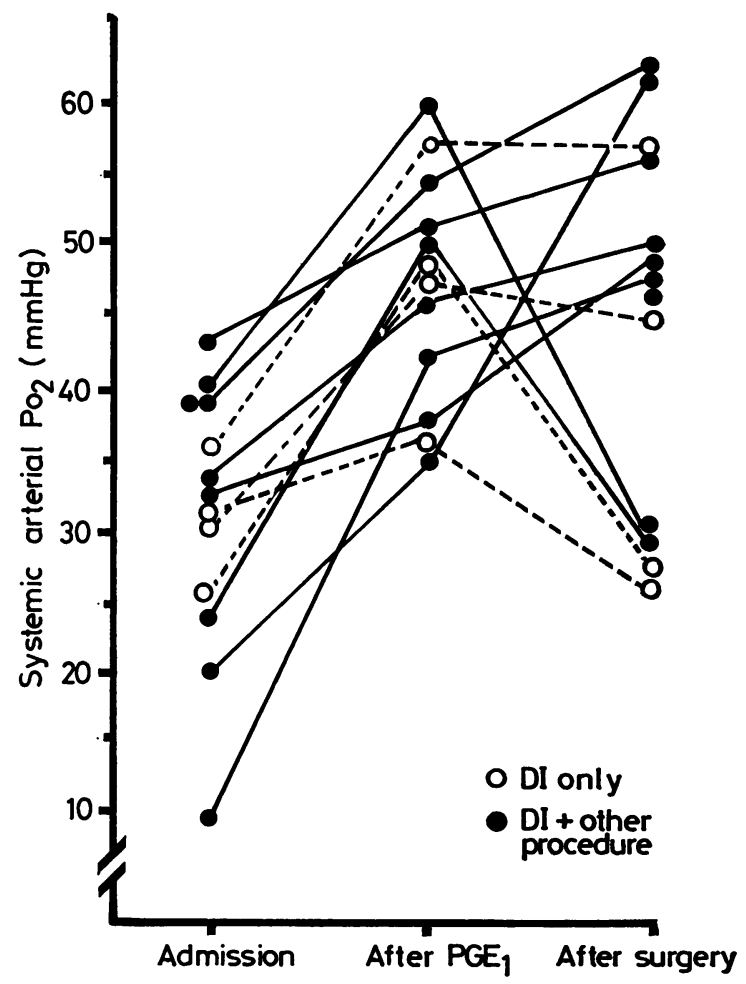

Fig 1 Graph showing changes in arterial $\mathrm{Po}_{2}$ after prostaglandin infusion and after formalin infiltration of the ductus arteriosus (prostaglandin discontinued). Mean $\mathrm{PO}_{2}$ on admission was 31 mmHg (SEM 2.6), after prostaglandin was $47 \mathrm{mmHg}$ (SEM 2.3), and after operation $46 \mathrm{mmHg}$ (SEM 3.5). 
postoperative period, between one and 15 days after operation. Three of these patients (cases 1 to 3 ) had undergone duct infiltration as the sole procedure. A continuous murmur had been present immediately after operation, but had subsequently disappeared: this was associated with a decrease in arterial $\mathrm{PO}_{2}$, suggesting that the ductus arteriosus had closed. Deterioration in these patients was rapid, and death occurrèd before further operation could be performed. The other two patients died one and eight days after operation from disseminated intravascular coagulation and septicaemia, respectively: at necropsy the ductus was patent in both cases.

\section{Early reoperation}

Four patients (cases $4,11,12$, and 13) required a second operation between two and eight days after the duct infiltration because of increasing cyanosis. None of these four patients was recatheterised before the second operation, but in all patients the continuous murmur, heard immediately after the duct infiltration procedure, had disappeared, with an associated fall in the systemic arterial $\mathrm{Po}_{2}$. Two patients had a standard right Blalock-Taussig anastomosis and two a modified right BlalockTaussig shunt using a Gortex conduit. Three of these patients subsequently died, between two and five months after reoperation (see late deaths below).

Cardiac catheterisation and angiocardiography were performed in seven of the eight patients who survived early operation, between two and 13 months (median eight months) after duct infiltration. One patient (case 4) died at home before repeat catheterisation could be arranged. In no case was the ductus arteriosus found to be patent. Four patients had undergone early reoperation (a systemic to pulmonary shunt) before restudy.

\section{Late reoperation}

Three patients (cases 5, 7, and 8) required a second operation for increasing cyanosis between eight and 10 months after the initial duct infiltration. This followed restudy which had shown closure of the ductus arteriosus. Case 7 underwent a right Blalock-Taussig shunt and cases 5 and 8 had a patch enlargement of the right ventricular outflow tract. Case 5 died in the early postoperative period.

\section{Late death}

There were four late deaths. One patient (case 5) died after late reoperation and the ductus arteriosus was closed at necropsy. The other three patients (cases 4, 11, and 13) died after discharge from hospital, at two, three, and five months after early reoperation (systemic to pulmonary shunt). In all three a closed ductus arteriosus was found at necropsy.

The outcome of the 13 patients who underwent duct infiltration is summarised in Fig. 2. Nine patients have died, an overall mortality of 69 per cent, and the ductus arteriosus has not remained patent in any patient who survived the immediate postoperative period. Only one patient (case 9) who had a pulmonary valvotomy with duct infiltration as the initial procedure has not yet required further operation, showing good right ventricular growth at follow-up angiocardiography.

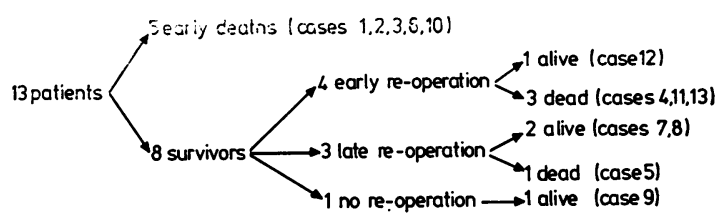

Fig. 2 Outcome of patients after formalin infiltration of the ductus arteriosus

\section{Discussion}

Formalin infiltration of the ductus arteriosus was introduced as a contribution to the management of infants with duct-dependent congenital heart disease in whom the standard procedures of pulmonary valvotomy and/or systemic to pulmonary shunt were not feasible or were inadequate. ${ }^{1}$ Good results have been reported when the technique was used as an adjunct to valvotomy and infundibuloplasty, ${ }^{3}$ but others have found it to be less successful when used alone. ${ }^{4}$ We have used the technique alone or in combination with pulmonary valvotomy in 13 patients. The aim of the procedure, however employed, has been to maintain duct patency and thus ensure adequate pulmonary blood flow in the medium term.

In our experience, formalin infiltration did not ensure duct patency even in the very short term. The majority of patients were weaned successfully from prostaglandin infusion without a significant fall in the systemic arterial $\mathrm{Po}_{2}$. However, in four cases the systemic arterial $\mathrm{Po}_{2}$ fell when prostaglandins were discontinued, and three of the patients who died early had lost the continuous murmur, suggesting duct closure. Four patients required urgent shunt procedures for increasing cyanosis within eight days of duct infiltration, and all surviving patients had occluded ducts at recatheterisation, between two and 13 months after operation. In only two patients, both dying at two and eight days after operation from non-cardiac 
complications of operation, was the duct found to be patent at necropsy.

All our patients had pulmonary atresia: with either an intact ventricular septum, a ventricular septal defect, or tricuspid atresia. They constitute a group of neonates in whom the overall mortality is very high and for whom the best approach to management remains controversial. When feasible, a good pulmonary valvotomy offers, in theory, the best palliation, establishing forward flow through a usually hypoplastic right ventricle, and improving pulmonary blood flow. The only child in the series surviving without reoperation (case 9) had a retrograde pulmonary valvotomy performed at the initial operation and was shown to have excellent right ventricular growth at follow-up. Pulmonary valvotomy is generally performed through a left thoracotomy which, in the presence of a left aortic arch, makes the creation of a Blalock-Taussig shunt or an aortopulmonary (Waterston) anastomosis difficult. Duct infiltration thus seemed an attractive alternative to contralateral thoracotomy for a shunt procedure, when pulmonary valvotomy alone was considered inadequate, on the operating table. Over the past four years in this unit, the use of a Gortex prosthesis as a subclavian to pulmonary artery conduit has largely overcome this particular problem. ${ }^{2}$ Nevertheless, even this alternative may fail for technical reasons, with the diminutive pulmonary and subclavian arteries of the neonate. Duct infiltration was, therefore, employed as a "holding manoeuvre" in the sick infant unfit for bilateral thoracotomy. Our experience with formalin infiltration, however, even in the short term, suggests that its efficacy is unpredictable-four patients required urgent intervention for deterioration with a clinically closing ductus while still in hospital. Long-term administration of prostaglandin orally may provide more predictable duct patency in the difficult situation of the sick neonate with an inadequate pulmonary valvotomy and a failed shunt on one side, if it is felt that further growth of the patient would increase the chance of a successful shunt on the other side. ${ }^{5}$ There is little experience with this form of treatment and the incidence of side effects from long-term prostaglandin treatment is unknown.

Thus, in our experience, formalin infiltration of the ductus arteriosus is no substitute for a shunt operation. Since the short-term effects of duct infiltration can be more reliably achieved by prostaglandin infusion, we have abandoned the procedure and would not recommend its use.

\section{References}

1 Rudolph AM, Heymann MA, Fishman N, Lakier JB. Formalin infiltration of the ductus arteriosis. $N$ Engl f Med 1975; 292: 1263-8.

2 de Leval MR, McKay R, Jones M, Stark J, Macartney FJ. Modified Blalock-Taussig shunt. Use of the subclavian artery orifice as a flow regulator in prosthetic systemic to pulmonary artery shunts. f Thorac Cardiovasc Surg 1980; 81 : 112-9.

3 Melo J, Norwood W, Freed M, Castaneda A. Formalin infiltration of patent ductus arteriosus (abstract). In: World Congress of Paediatric Cardiology Abstract Book. London: CIBA: 1980; 60.

4 Hatem J, Sade RM, Upshur JK, Hohn AR. Maintaining patency of the ductus arteriosus for palliation of cyanotic congenital cardiac malformations. The use of prostaglandin $E_{1}$ and formaldehyde infiltration of the ductal wall. Ann Surg 1980; 192: 124-8.

5 Silove ED, Coe JY, Shiu MS, et al. Oral prostaglandin $\mathrm{E}_{2}$ in ductus dependent pulmonary circulation. Circulation 1980; 63: 682-8.

Requests for reprints to Dr J F N Taylor, The Hospital for Sick Children, Great Ormond Street, London WC1N 3JH. 